\title{
Celebrating Translation as a Bridge between Knowledges and Cultures*
}

\section{Avadhesh Kumar Singh}

\begin{abstract}
$\underline{\text { Abstract }}$
With the establishment of Translation Studies as a discipline, translation is being critiqued and celebrated in different ways. The celebration of the Translation Day demands its study from the perspective of multiple translation traditions in various civilizations. While the paper sees the Translation Day as a trope for celebration of translational endeavours all over the world, it proposes consideration of the translation as a bridge between knowledge and cultures from non-Eurocentric perspectives.
\end{abstract}

Keywords: Translation Day, St. Jerome, Narada, Hermes, Kumarajiva, Dara Shukoh

\section{Discussion}

Days are rage these days. Father's Day, Mother's Day, Valentine's Day, Friendship's Day; name it and the Day is there. Celebrating a day for something or other is such a craze these days that almost every day of a year is labelled after something or other. It seems that the spree of Days would soon outnumber the days in a year. If the trend continues, after sometime when we would be short of days, we would be compelled to celebrate half a day or quarters of a day after something or other. Translation Day is another addition in the sequence of Days around us. Needless to mention it here that overdoing leads to vulgarity. But none of us would have any problem with the Days if they are for a good cause like translation.

Translation Today Vol.10, Issue-II, 2016 
Things as they are, on the occasion of celebrating Translation Day let me take this opportunity to be a little polemical and speculative about translation and the 'day' as well.

In his book Civilization: West and the Rest (2011), Neil Fergusson writes that if we were to go round the world in 1411, the best would have been in the Orient. But things have changed by 2011, as the Occident changed the picture with six attributes developed and employed by it: Competition, Science, Democracy, Consumerism and Work ethics. For this paradigmatic shift in which the West proposes, and the rest follows, he could have added one more as the seventh factor i.e., translation to it, for the West appropriated the intellectual resources of the rest of the world through it, and made it its own. The attendant Eurocenterism tried to establish Europe or the West as the fountain head of everything on the earth including translation. It is then not unnatural that the Translation Day is also to be named and celebrated after someone from the West. In the process, the west lionizes itself as the inventor of translation for the rest of the world that genuflects before its theories and criteria of translation. The consequence of this uncritical acceptance of everything from the west is that what makes $30^{\text {th }}$ September the International Translation Day? The reason is that St. Jerome died on this day in 420 AD.

St. Jerome (347 - 420) was a Latin Christian priest, theologian and historian who translated most of the Old Testament from the Hebrew version, known as the Vulgate. So immense was his erudition that St. Augustine (August 28) is said to have remarked of him, 'What Jerome is ignorant of, no mortal has ever known.' He was as a master of Latin, Greek, Hebrew and Chaldaic. As 
mentioned in Butler's Lives of the Saints, a pope is said to have remarked, on seeing a picture of Jerome striking his breast with a stone, 'You do well to carry that stone, for without it the Church would never have canonized you.'

St. Jerome knew Greek, and learnt Hebrew before he started his translation project. Later on, in Jerusalem he honed his understanding of Jewish scripture and commentary on it. In 382, he began correcting the existing Latin version of the New Testament, commonly known as the Vetus Latina. In 390, he focused his attention on translation of the Bible from Hebrew. He completed this work by 405. Prior to Jerome's Vulgate, all Latin translations of the Old Testament were based on the Septuagint and not the Hebrew. He decided to use a Hebrew text instead of the previously translated Septuagint, much against the advice of Christian clergy and scholars (including St. Augustine) who were of the view that the Septuagint version was inspiring in its effect. Along with this translation he wrote a number of commentaries on the Scriptures.

As a writer, St. Jerome is considered next to St. Augustine in ancient Latin Christianity in terms of the corpus of his writing. The Roman Catholic Church recognizes him as the patron saint of translators, librarians and encyclopaedists. He contributed to the domain of history with his Chronicle known also as the Chronicon or Temporum liber (380) in Constantinople which is a translation of the second part of the Chronicon of Eusebius into Latin with a supplement that deals with the period from 325 to 379. Apart from his exegesis and commentaries, the book De situ et nominbus locorum hebraicorumis a translation of the Onomasticon with his additions and corrections. Here special mention needs to be made of the translation of the homilies 'In Canticum Canticorum, of which the Greek original has been lost. 
Often history tends to be kind to some, and otherwise to others. St. Jerome has been a beneficiary of favourable glance of history. His translation of the Bible is often not considered the most critical edition, and its acceptance by the Church was providentially fortunate. With no intent to discount his contribution to the field of translation, it would not be appropriate to mention that in view of the contribution of many to the domain of translation in the world like Kumarajiva, John Wycliffe, Eitenne Dolet, Martin Luther, Dara Shukoh, William Jones and Fredrik Max Muller among others, St. Jerome seems to be rather fortunate to have his date of departure from this world to his heavenly abode as the International Translation Day. Eurocenterism seems to have swung the pendulum of time in his favour.

Academic domain does not permit us to either censure or celebrate uncritically. In view of the above let us use the event of the Translation Day to speculate alternatives to St. Jerome, to avoid uncritical celebration of everything given to us by the West. The derivate to the above would be the question: Was there not even a single individual outside Europe, in India, China or Persia with rich knowledge cultures of at least 3500 years who did contribute to the domain of literature that his/her birth or death day may be considered as the translation day?

Let us explore a few alternatives and justification for the choice. Mythopoeia as a human activity contains traces of collective un/conscious; hence the quest may begin with mythology from the east and the west. 


\section{Narada:}

Narada, among chief gods in the Hindu pantheon, is an interlocutor, messenger of gods and a link between the divine and human worlds. Since gods in all mythologies speak in classical languages only, Hindu gods also speak in Sanskrit. Human beings on the other hand use Bhasha-s. In these linguistic zones, though the gods are supposed to be omniscient, it is Narada who receives and understands the message of gods and translates it in the language/s of the people in order to transmit it to them. Also what he hears from human beings in their deshbhasha-s (language of the region), he translates it into Sanskrit, devabhasha or the divine language to 'carry it over' to immortal beings. Thus, as a translator between two worlds he acts as living bridge between different worlds. Translation being the principle means of his communication, he is the presiding deity of translation, as the domain of translation cannot be without its god.

The association of translation with Narada, a god of wisdom, aligns translation with wisdom. These attributes of Narada's wisdom may be proved by many instances in the forms of drsahtanta, narratives as illustrations. Lord Krishna in the Gita calls him as the foremost of all sages. However, his wisdom does not prevent him from learning from others. In the Chhandogya Upanishada, a narrative deals with his quest for self-knowledge (atmagyan). He approaches the sage Sanatkumar for lessons in spirituality. Sanatkumar, one among the first four sannyasins, was a sibling to Narada, as they were fathered by Brahma. On being requested Sanatkumar asked Narada to tell him what he had already learnt. Narada enumerated the domains of his knowledge that he already knew as the Rig Veda, the Yajur Veda, the Sama Veda, and the Atharvaveda, itihasas and the Puranas, and vyakaran (grammar) as 
the means of understanding the meaning of the Vedas, Mathematics, natural science, Mineralogy, Logic, Ethics, etymology, the Fine Arts, science of rituals, Astrology, the science of warfare, and material sciences among others. But even after this gargantuan study, he added, that he was only a mantravid, a knower of shastra-s or learned texts, not an atmavid, knower of the Atman or self. Sanatkumar imparted the knowledge of Brahman or the Infinite that knows no difference to Narada. The incident proves that knowledge is no guarantee of peace of mind. Only the knowledge of the Self can give one peace of mind. Self-knowledge or the knowledge of Brahman is called parāvidyā, or supreme knowledge, and all else is inferior knowledge, aparavidya. In the ancient Greek temple of Oracle of Delphi, the sentence written was 'Know Thyself.' William Shakespeare went a step ahead and said in Hamlet, 'To thine ownself be true.' If Narada is a god of translators, the lesson to be learnt from him is that translators have to know themselves and be true to it.

Endowed with an extraordinary vision and memory, he is able to act in harmony with imperceptible divine design. His attributes become evident in the conversation between Yudhishthira and Bhishma. In the 'Bhishma Parva' of the Mahabharata,Yudhishthira wished to know from Bhishma who was lying on the 'bed of arrows' in Kurukshetra as to who was dear to all, gladdened all, and was endowed with all merits and accomplishments. Bhishma related Krishna's words to Ugrasena, who wanted to know why everyone spoke so highly of Narada. He enumerated the attributes of Narada that he was as learned in the scriptures, noble in conduct, yet not proud or boastful, without anger, impudence, fear, and procrastination, committed to his words and untouched by passion or greed, a man of spiritual knowledge, forgiving, self-possessed, 
simple, truthful, intelligent, and modest, austere, good-natured, eloquent, soft spoken, decorous, pure, amiable, devoid of malice, and an expert in music, untouched by sin, a renouncer and dispenser of knowledge, an immensely learned, wise, free from passion, deceit, laziness, greed, anger and a man of unflinching devotion, a master of his own self, and always open to instruction from others.

As a paragon of virtues, Narada can visit anybody, anywhere and at any time, gods, demons, or human beings. His acceptance emanates from the fact that he is a sincere counsellor. Mere recitation of 'Narayana! Narayana!' by him gives him access to all worlds. In modern parlance, it is his master password to open systems or master-key to open doors of all worlds. The virtues of Narada recounted are far too many for anyone to emulate. However, the fact remains that a translator should never be proud of her/his talents or achievements, for translation is an act of modesty, as it begins with the recognition of the existence of the other and its acceptance in a new linguistic system and culture.

Notwithstanding, his inventory of knowledge of disciplines, skills in fine arts and wisdom, there are times when Narada behaves like a common person, even like an ignorant one. This lends his character an intriguing aura. The narrative runs that once Narada became a little proud of his musical abilities in playing the Veena as skilfully as he did. Lord Vishnu came to know about it and thought that His devotees should not suffer from pride and arrogance. For this purpose, He took Narada for a stroll in a forest where they heard someone weeping. They followed the sound, and found some women with terribly deformed bodies crying in pain. Vishnu asked them who they were and why they were weeping. They replied that 
they were the Raginis (the deities of music), and their bodies were disfigured by Narada's erroneous selection of notes, for he is devoid of musical sense. His singing, out of tune with his music, had disfigured them. At this, Narada realised falsity of his arrogance. The narrative about Narada, god of translation is that arrogance on the part of translators would lead to torture of texts and even words like the women in the narrative. Along with being a messenger of gods Narada is the collective unconscious of human beings that at times suffers from frailties and foibles of human beings. His Veena is an instrument of communication and symbolic of creative faculty. However, there is a diametrically opposite perception in loka (common people) about Narada that he was given to inciting illfeeling and quarrel, and infamous for intrusions at awkward times. For activities such as these he had earned the sobriquet 'piśuna' i.e., a spy, and a slanderer who is given to backbiting.

The elongated discussion about Narada was aimed at legitimising Narada's case as the god of translators with due cognizance of perception about his proficiency in communication in different worlds, 'wisdom' and 'spying'. These epithets of Narada become appellations of translation, as they are carried over.

Despite the temptation of pronouncing Narada as the god of translators, the problem is that we may not be able to have International Translation Day after him, as Indian minds obsessed with diachronic time may like to know his date of birth or death. Narada's divinity, however, prevents him from laying the claim, for he is immortal as a god, and free from birth and death. To have translational day named after him, Narada needs to opt for a change 
from his status as an immortal god to a mortal being. He will have to suffer from death so that the day can be celebrated as the international translation day. This is the sacrifice that neither Narada nor his devotee would be willing to make.

For the western counterpart, it is possible to examine the claim of Hermes with full realization of the predicament of this endeavour, as that might court the same end.

\section{Hermes:}

Like Narada in the Hindu mythology, Hermes in the Greek mythology as the god of transitions and boundaries, lays claim to be the god of translation. His name 'Hermes' is derived from Greek word 'hermai' i.e., 'boundary' markers. He is a patron of travellers' herdsmen, orators and wit, litterateurs, athletes, traders and even thieves. 'Hermes' may be related to Greek 'hermeneus' or interpreter, reflecting on Hermes' function as divine messenger. The word 'hermeneutics', the study and theory of interpretation, is derived from hermeneus. Plato, while examining the etymological derivation of Hermes's name, found it derived from the divine messenger's reliance on eirein (the power of speech). The fact, however, is that like Narada, he too moves freely between the worlds of the mortal and divine, as an emissary of the gods, an intercessor between mortals and the divine. Also he is a conductor of soul into the afterlife. As a tribute to his faculty of delivering messages, interestingly enough, the Greek post office has Hermes as its symbol. In some myths he is a trickster (similar to 'Pishun' in case of Narada), and outwits other gods.

As the messenger of divine and herald of the Gods, he wears the gifts from his father. C. G. Jung saw Hermes's attributes as the guide to the underworld and interpreted him as the god of 
unconscious, the mediator of information between the conscious and unconscious forces of the mind, and the archetypal messenger between different realms. As the guide for the inner journey, for Jung, as the trickster he is the guide for the psychotherapy. But the problem is that despite all attributes, almost similar to Narada, Hermes' divinity deprives him of laying any claim to have International Translation Day after him.

The situation then compels us to turn to the mortal world, and seeks a worthy contributor to the domain of translation who can be considered for celebrating the International Day. In the midst of various contributors, it is Kumarajiva, a contemporary of St. Jerome who emerges taller than others. Hence, he needs more elaborate treatment than others.

\section{Kumarajiva:}

Among various seers, enunciators and disseminators of Buddhism, Kumarajiva is one of the most outstanding presences in the history of Buddhism. He not only studied Buddha's philosophy but also lived it. He captured the essence of Buddha's preaching and the wisdom implicit in them by focussing on crucial terms. One such term is 'shoonyata' (emptiness), which is frequently encountered in Prajnaparamita writing as well as in those of the philosophical movements that take its inspiration from them, the Madhyamika ('Middle Way').

The principle sources from which the life of Kumarajiva may be carved out include Sangyou (445-518) in Chaui Sanzang (Collected Records on the Making of the Tripitika), Huijiao (497554) Gaoseng Zhuan (Biographies of Eminent Monks, and Boachang (464-514) Mingsen Zhuan (Biography of Famous Monks). 
Sangyou's work is the ur-text of Hujiao. Among the later ones, the biography of Kumarajiva in Jin Shu, written in the $17^{\text {th }}$ century, is a combination of the elements from the biographies by Sengyou and Huijiao, though in abridged form. It excludes his sexual transgressions. These form a part of the biographies of ' $g a o^{\prime}$ (eminent) and ming (famous) people, for Kumarajiva was ' $\mathrm{gao}$ ' and 'ming' both, though eminence and fame both persuade their subscribers to foreground and background attributes of the agency depending on the individual or social orientations.

However, three things made me curious to peek in the life of this great translator-monk: the character of his mother Jiva, her exhortation to Kumarajiva to disseminate Buddhism, and treatment of Kumarajiva's sexual transgressions as against his much known abstinence and incontinence or incompetence to produce his biological clones. Even at the risk of repetition, it would be appropriate to underscore a few aspects of Kumarajiva's life, for he is history, legend and myth combined in one. His life, the way he lived and is known, and his translations are intertwined. His parents, Kumarayana and Jiva, each gave a part of their names to him and called him Kumarajiva.

In case of Kumarajiva, the distinction between biography and hagiography gets considerably blurred, as most of the elements of hagiography i.e., vita, passio, inventio, translatio, visio, and miracullum are absent in it. Surprisingly, his mother Jiva gets considerable space in early biographies by his followers, something rare in the medieval Chinese period. She was reputed as a woman of sharp wit and vast memory. She had a red mole on her body that was then considered symbolic of her mothering a wise child. She was fluent in Indian language without having formally learnt it. She became a nun after the birth of the second son, Fushatipo or 
Pushyadeva, who might have followed his father's path rather than his mother's, as details about him are not available.

Jiva took keen interest in Kumarajiva's education and intellectual development. After Kumarajiva was grown up and educated, Jiva is said to have stated the following profound statement with a question:

The teaching of Vaipulia should be widely propagated in the Zhendan (that is China). Its transmission to the Eastern Land will depend on your strength; yet as such it will not benefit you. What will you say to that?

Kumarajiva responded to her mother's query thus:

The way of the Mahasattvas is that he benefits others while forgetting about himself. If I must help to disseminate the teaching of great transformation, to wash away the blindness and to enlighten the ignorant, even if my body is to enter the furnace and store, I shall suffer without regret (in Huijiao's description)

It was a moment of Kumarajiva's evolution from a prodigy to psychological and spiritual independence. Jiva not only mothered Kumarajiva but planned and envisioned the course of her son's life. In the poem, Kumarajiva, it may be seen in the dialogue between Jiva and Kumarayan pertaining to Kumarajiva's future and the role that the parents should play in the child's development.

Jiva was a combination of the model mother and the model Buddhist practitioner fulfilling the medieval Chinese social expectation of a model mother before entering the monastic order. The role that Jiva played in Kumarajiva's life may be discerned from 
two related facts. The first pertains to the silence about her second son Fushatipo or Pushyadeva in social psyche and in the Chinese medieval records. Had Jiva not been oriented towards Buddhist monastery life that she embraced even after initial resistance from the family, particularly her husband, she would have perhaps chiselled a different course for her younger son too. The second is related to the life of Buddhayasas, Kumarajiva's contemporary. $\mathrm{He}$ was no less distinguished than Kumarajiva except that he was not illustrious royal by birth. Buddhayasas was proud in his demeanor, and thought of himself as knowledgeable and wise, and used to say that few were qualified to be his teacher. Thus, he was not respected by the clergy. It was Buddhayasas who introduced Mahayan ideas to Kumarajiva. Also, when Kumarajiva was exposed to the charges of sexual transgression, Buddhayasas had openly sympathized with Kumarajiva. The question often asked is: Why did Buddhayasas's erudition contribution not achieve recognition in comparison to Kumarajiva? The answers may be many, as they may be seen in the words of Jiva who ordained Kumarajiva to propagate Buddha's message in China with 'strength' but without expecting any 'benefit'. He implemented his mother's words without limiting himself to becoming an erudite scholar. He, along with acquisition of scholarship, focused on meditative aspect of Buddhism and translated Buddhist texts. Also he completed incomplete translations with Acharya Vimalkirti during his visit to Chhang-an. His translation project that involved about two thousand scholars and translators and led to translation of at least three central Buddhist texts was in consonance with the spirit of his mother's words. Also, along with transforming lives of his disciples and people of his generation with the message of Buddha his translations were concrete evidence of his contribution for the subsequent generations to avail themselves of them. 
Kumarajiva is recognized as one of the greatest translators of Buddhist scriptures from Sanskrit into Chinese. His translational transactions led to the transmission of Buddhist religious and philosophical ideas in China and beyond. His principal translational endeavours include translation of the central texts of the Madhyamika School of Buddhism that later became the basic texts of the Chinese Sanlun, known in Japanese as Sanron (Three Treatises) School of Buddhism. In the process he translated Buddha and his preaching to the people of the east (China) for whom Buddha existed as a name, and if they knew him/them the perceptions that emerged were distorted in absence of erroneous translations. In Kumarajiva's translations, the people found their own Buddha in a new avatar facilitated by Kumarajiva.

With his encyclopaedic knowledge of Indian learning in Sanskrit, he democratised Buddha's message to the people with his translations in Chinese language. In this sense, he stands out as prefiguration of the Bhakti poets, who almost one thousand years after Kumarajiva made the abstract knowledge of the Vedas and Upanishada-s available to the common people by transmitting it from Sanskrit into the languages of people. His life and its philosophical underpinning in relation to human condition, being, world and way to live in the world meaningfully are dealt with in Kumarajiva: A Poem (2015) by Kunwar Narain in Hindi.

\section{'Translation not a Guest House but a Home': Kumarajiva, the translator}

Political history formed Kumarajiva while he shaped cultural history for future to an extent that it transformed the Chinese way of thinking and living. In 379, Fu Chien or Fu Jiān conquered the city of Hsiang-yang or Xiangyang and established his capital at Ch'ang- 
an which was famed as a centre for the translation of Buddhist scriptures and texts. Hearing about Kumarajiva's spiritual, philosophical and linguistic abilities, Tao-an urged $\mathrm{Fu}$ Chien to invite him to Ch'ang-an. In 385, Tao-an died, and six months later the Yao family conquered Ch'ang-an and killed Fu Chien. The new dynasty continued many of the previous rulers' policies, as it preserved Tao-an's translation centre, and encouraged Buddhist studies. Thus, it paved way for Kumarajiva's arrival in the capital.

Yao Hsing received Kumarajiva with the title 'Teacher of the Nation.' Within six days of his arrival in Ch'ang-an, he began to translate a text on meditation, the Tso-ch'an san-mei ching. In the Translation Centre, supported by Yao Hsing, Kumarajiva found himself surrounded by a large group of knowledgeable monks who worked under the translation project under his guidance. He reorganized the Centre for new translations and review and revision of the preceding translations. Within the next few years, he translated almost 50 works in about 300 volumes.

Before embarking upon translations, Kumarajiva learnt Sanskrit and studied texts of Indian knowledge systems like medicine, astronomy and astrology, exegetical and hermeneutical methods of exposition, logic and the applied sciences along with learning the scriptures and treatises of the Sarvastivadin School, Dīrghāgama and Madhyāgama. His translations included the Diamond Sutra, the Amitabha Sutra, the Lotus Sutra, the Vimalakirti Nirdesha Sutra, the Mulamadhya Makakarika and the PanchvinshatisahatrikaPragyaparmita Sutra.

With his translations Kumarajiva lent a new dimension to the Chinese methodology of translation. He questioned, the Tao-an method, the ko-i-or 'matching the meaning' method of translation, in which unfamiliar Sanskrit Buddhist concepts were replaced by 
known Chinese Taoist words. He was of the opinion that the practice compromised Buddha's teachings. However, in the process of reviewing Tao-an's work, he realized that too strict an insistence on literal translation that sometimes required the creation of awkward neologisms, rendered beautiful texts obscure. He believed that a translation should accurately convey the tone and texture of a teaching inseparably from its content. With this conviction he adopted a new methodology for translation, emphasizing the central theme of a text and editing the passages which would seem unnecessarily repetitive to Chinese readers. In other words, he employed the strategy of deletion of such parts as were extraneous to the central text by questioning the propriety of repetition of passage. To achieve this purpose, he would assemble a large working force that may be termed as a guild of translators. Then he read a text aloud to them, sentence by sentence. His disciples, including Yao Hsing would hold the original palm-leaf manuscript, in their hands while Kumarajiva explained it. After each sentence, Kumarajiva would explain its meaning and provide an oral translation in Chinese. It was followed by comments and improvements suggested by the assembly of disciple-scholars. The appropriate suggestions were incorporated into it. The translation thus approved was written down, and then reviewed by an editor from the viewpoint of style and internal consistency. Finally, a calligrapher would correct the Chinese ideographs to ensure that there were no ambiguities in transmission of the texts.

Translation is essentially a collaborative act. Kumarajiva's translations were collective works of Kumarajiva and his colleagues, though for the sake of prestiging, credit is reserved for Kumarajiva, the individual. His was an intellectual collaborator that produced texts which were readable, comprehensible and inspiring. His works became the foundation of the great movement of Buddhist thought 
and teachings that ascended in China, even at a time when they dwindled in India and began to face stiff resistance from other religious quarters. In this regard it is necessary to mention two factors i.e., the support of Yao Hsing to the project, and the wholehearted cooperation of the scholarly monks who played their roles in the success of the project. Kumarajiva acknowledged their contribution suitably.

Kumarajiva revolutionized the Chinese Buddhism by bestowing clarity upon Buddhism and overcoming the former system 'geyi' or concept-matching system of translation through use of Daoist and Confucian terms. His style of translation was distinct, as it had a flowing smoothness reflecting his focus on conveying the meaning which was opposed to preceding practices of precise literal rendering. It made his translational renderings of the Mahayana texts attain acceptability and recognition in comparison to precise and literal translation, for instance by Zuangzang.

His translational practices are a case study in methodology of translation. However, his personal life came to be entwined in relation to his translational practices. Though he sustained himself in the in/famous Chinese project of manufacturing his clones by allowing maidens to bear his children, yet there were at least three alleged instances of sexual transgression. These alleged acts of sexual transgressions are often linked with his loose translations. The issue of fidelity in translation has been associated with gender till feminists objected to it. It was a prefiguration of the same attitude towards translation, though it was directed at an individual's morality or laxity of character. His disregard for the monastic codes earned him censure of his critics. Such slackness led other 
practitioners of the Buddhist order and translators to suspect his sincerity. To them, his lack of understanding and interpretation of the text and loose translation could be seen in both in his translations and in his casual attitude towards sex.

Notwithstanding these interesting co-relations between Kumarajiva's life and work, the poet Kunwar Narain's Kumarajiva meanders through the dark chambers of sexual transgressions by taking no note of them. However, the poet deals with the Emperor Yao's project of mass manufacturing of Kumarajiva through biological mating of Kumarajiva with maidens. He resolves it with the help of discussion between the young maidens provided by the emperor for mating with Kumarajiva. In this Kunwar Narain sees an instance of human grossness that sees biological/material/physical solution as the solution of all problems. In a sense, it may be proposed that in the project, Kumarajiva was the source text both, the maidens the medium (i.e., the language), and unborn Kumarajivas the target texts. The project failed because the source text cannot translate itself, and Kumarajiva who could have been the translator was not physically and ideologically willing to oblige.

Kunwar Narain paid his tribute to Kumarajiva, the translator, thinker, author, poet in poetic terms in his poem Kumarajiva. His Kumarajiva tries to enter the text and its world of words that create a new time, sub-time and counter-time. For him--

Every treatise is a closed door

I open it and enter into words

And I take bath

In that perpetual waterfall of Time

That is the Time of that language. (31-32) 
Expostulating his views pertaining to translation and translator in the poem Kunwar Narain, the poet, rejects the hierarchical notions of source and target text, and author as superior to translator. His Kumarajiva chooses his path with care, and announces it thus:

But I have already chosen my path

I have not to be a preacher of Buddhism

I want to be a student-translator-scholar and interpreter

Of texts of Buddhist philosophy.

Kumarajiva's statement proves that a translator is a combination of 'student-translator-scholar and interpreter'. What needs to be added is that s/he has to be competent in language, if not necessarily a linguist. The so-called mother-tongue of Kumarajiva was Tosharian (Tokharian) which belongs to Indo-European language family. Its new form is still in use in Kutcha. He learnt Sanskrit and Chinese languages later on. What lent direction to his endeavour was the objective of his translational enterprise. He used his translation as an instrument for removing ignorance.

Words are lamps in the world which would be in darkness without them. Ideas in a language remain confined to it in absence of their transference in another language. Kumarajiva changed the orbit of Buddhist ideas by transmitting them into Chinese. In the process he gave a new direction of Buddhism with its circulation in China. He says:

My main objective is

to transmit Buddhist philosophical treatises

Into Chinese from Sanskrit and Pali

With full sensibility and culture

The sweetness that I hear in Sanskrit language

I wish to preserve its echoes in Chinese also. (59)

He was not content with translation only. 
He wanted to communicate

Sounds and echoes

Of splendor and sweetness

Of Sanskrit language and poetry

Into Chinese and Tushari Languages

That became meritorious attributes

Of his translation. (71)

Seen from this perspective, the attributes of a good translation are attributes of a good artist or poet. Translation, like other art forms is a mode of communication of ideas and emotive feelings from one mode of communication to another. Artist or scientist deals with experiences - fictive or factual or both-and ideas-inferred from his/her experiences or provided by his/her intuition or imagination or bucketed out from the ocean of the collective human unconscious. S/he then chooses the medium - language-poetry or prose, painting, dance, music, sculpture or architecture. S/he has to wrestle with the medium to transmit her/his thoughts and feelings to do justice to their depth and shades. All along, the artist sublimates the gross, and journeys from sensual to spiritual. In the process the poet punctures the myth of translator being the native speaker of the source or target language. Neither Sanskrit nor Chinese was Kumarajiva's 'natural' languages. He did it so well that in his case translation, creativity and spirituality became synonymous.

And this creativity

Is the sum experience of spirituality.' (176)

In this category of creativity, translator is included. But the translator's job becomes a little more difficult as s/he has to understand, interpret and carry over meaning or sense along with, to use Kunwar Narain's words 'sounds and echoes of splendor and 
sweetness' of the source text in its new abode. Kumarajiva succeeded in his endeavors as a translator, as the poet Kunwar Naraian words his approval for his ability to transfer:

'Sounds and echoes

Of splendour and sweetness

Of Sanskrit language and poetry

Into Chinese and Tukhari Languages'

And he continues it---

'Kumarajiva's enthusiasm

Did not decrease

Even after

Translating lively

More than three hundred

Buddhist texts from

Sanskrit to Chinese

He wanted

To transfer entire Buddhist discourse from Sanskrit

Into Chinese language

In such a creative manner

As if it were its own literature

He wanted to make their home in translated language

Not mere its guest house.' (173)

Here Kunwar Narain makes a major statement regarding translation. If Kumarajiva is a good translator, then the good translation is a 'home', not 'a guest house.' The former is where the source text feels at home, forever. It is not a make shift arrangement. Since the poets speak the language of metaphors, so a translator becomes a diver. A creative artist is also a diver. The poet writes about his translator:

Translating Buddhist treatises

With his disciples 
Like a diver

He would bring away rare pearls of word

From the fathomless sea

Their splendour

Used to astonish all. (174)

This is the tribute by a modern Hindi poet to Kumarajiva's translations. He does not question validity of translations, and keeps himself away from questions that have been raised particularly regarding deletion of repetitions in his translations. More than three hundred years after him, Huen Tsang who had appreciated Kumarajiva's translations but objected to this practice, as he subscribed to the traditional Chinese method of literal translation.

Kumarajiva encountered the questions that are still echoed in translation circuit. Should the translation be readable like the original or some liberties may be enjoyed? Before him the system of 'pairing' i.e., the use of similar idiom into target language-- was in vogue in Chinese language. For instance, if there was in an 'utterance' or 'discourse' of Lao-Tse or Confucius similar to Buddha's, it was not considered inappropriate to accept it and use it as equivalent to Buddha's. Kumarajiva intervened in it. Commenting on this aspect Kunwar Narain writes that Kumarajiva's perspicuity pointed out this foundational visanagati (inconsistency) in the Chinese practice. He understood that in order to preserve the sacredness of Buddha's thoughts, he will have to invent a new language without relying on borrowed idiom. This was a major task that he accomplished with ease and trained his disciples accordingly. (Kunwar Narain, 2013, p.122) Does the source poem take a new birth in translation or it just changes its clothes? According to Kunwar Narain, Kumarajiva preferred the first alternative (idem). 
The result was that poetry and philosophy were transmitted and coexisted in Kumarajiva's translations symbiotically:

The treatises like Madhyamika, Pundrika Sutra and Pragyaparmita

Were not mere translations

But in them was preserved

The sweetness of poetry (174-175)

His invaluable translations became immortal in Chinese, Japanese and Korean languages and literatures. The poet avers:

This process was not merely translation

But an unprecedented instance of

Of a profound confluence of friendliness

Between two languages. (175)

That is what translations do, as with them two languages, their knowledge, histories and cultures meet and the site becomes an embodiment of mutual cultural illumination. Elsewhere Kunwar Narain sums up Kumarajiva's contribution as a translator thus:

... Kumarajiva carved a unique space for Buddha's thoughts in Chinese language by extending the work of a translator. His endeavor was not a mere linguistic transference but was creativity of highest order that not only contributed something new to Chinese language but also established Buddha's thoughts in a new time, space and language - by the side of Lao Tse and Confucius, not below them. (Kunwar Narain 122)

If one looks at the metaphors and concepts used by Kunwar Narain, it seems that they may be used for an artist or a translator as well or for that matter for any sort of creativity. Rather than stopping 
here the poet elevates creativity to spirituality of highest level which has nothing to do with religious or irreligious categories. What is it then? The poet explains it thus:

A creative work is spirituality of highest order

It is a restrained transformation

Of energy in the direction of sublimity

The meditator and the object of meditation

Become one

In creativity

And catharsis of his righteous instincts

Assumes a new form.

Spirituality is neither religious nor

Irreligious

That attains identity of spiritual in temporal

Of man's spiritual powers

With its re-establishment in his text.

With the re-habilitation of man's spiritual power in a new text In this temporal world.

It is a re-entry of consciousness in life

Not its boycott; though they are different

But not contradictory.

This resolution of elements

Is not merely physical

Consciousness has that independent power

That it can create

Absolutely original concept

And this creativity

Is the sum experience of spirituality.

Translation is an act of creativity, hence of spirituality. But this spirituality is experienced by consummated translators only.

Kumarajiva's journey as a translator teaches us the way he lived in the midst of tumultuous times that failed to prevent him from 
translating the message of Buddha. In the process he proved that cultural history that is often filmed by the material success and luxury of political powers is more potent than political history. The irony of his life was that more he wanted to tread a path of 'voluntary poverty' (swechchhiknirdhanta) more he was snared by wrangling of regal authority. Yet he remained undeterred and played his role as an inter/cultural transnational ambassador in Asia.

If translation is a transnational activity that lays cultural bridges and celebrates life of ideas by carrying over it into a new system with a definitive methodology, chosen consciously, the International Translational day needs to be named as Kumarajiva Day. Among all great translators in the world, Kumarajiva was a true transnational in terms of his parentage and areas of translational operation. The problem, however, is that in his case the year of his birth or death is known to us but not the day and date. Hence, Kumarajiva, a senior contemporary of St. Jerome, despite all qualifications and corpus of translation day cannot be celebrated after him due to non-availability of dates of his birth and death. As a consequence, we will have to look for other alternatives in the form of Dara Shukoh.

Dara Shikoh (20 March, 1615 - 30 August, 1659):

In the long history of India's intellectual and cultural history the person who deserves to be celebrated for his contribution to translational enterprise is Dara Shukoh, the eldest son and the heir apparent of Mughal Emperor Shah Jahan.

Dara Shikoh is among the most erudite enlightened living paragons of the harmonious co-existence of heterodox traditions in the Mughal history of India, as he supported mystical religious speculation and of syncretic cultural interaction among people of different faiths, and lived and paid for it too. His approach made him 
a heretic in the eyes of orthodox clergy and obscurantist religious extremists including his brother Aurangzeb who killed him after ascending the throne. Through translational synthesis he was creating a third path with the Hindu and Islamic philosophies. Unfortunately, like translators in the medieval Europe he too suffered persecution, as his fatal end to some measure was determined by the perception of his translational project.

Dara was a mystic who followed Sharmad Kasani, a Persian mystic, as well as Quadiri Sufi saint Hazarat Mian Mir, whom he was introduced to by Mullah Shah Badakshi. Mullah Badakshi was Mian Mir's spiritual disciple and successor and was so widely respected among all communities that he was invited to lay the foundation stone of the Golden Temple in Amritsar by the Sikhs. This fact deserves to be mentioned, as Dara was later to develop friendship with the seventh Sikh Guru, Guru Har Rai.

Dara devoted much endeavour towards finding a common mystical language between Hinduism and Islam. Towards this goal he completed the translation of 52 Upanishads from Sanskrit into Persian in 1657 so that it could be accessed by Persian Muslim readers and scholars. In his translation of the Upanishads entitled Sirr-e-Akbar (The Greatest Mystery), where he speculates his hypothesis in the Introduction that the work referred to in the Quran as the 'Kitab al-maknun' or 'the hidden book', is none other than the Upanishadas. His other celebrated work, Majma-ul-Behrain i.e., 'The Confluence of the Two Seas', was also devoted to a revelation of the mystical and pluralistic affinities between Vedantic and Sufi philosophies. Apart from the above, the tradition credits him with the translations of the Yoga Vashishitha and the Bhagvat Gita from Sanskrit into Persian. 
Translation of just the Upanishads warrants a place of eminence to Dara in the history of translation in India. Apart from the synthetic objectives that he had, the methodology and elasticity without sacrificing the ideas in his approach demands our attention. His translational project included, along with other Sanskrit and Persian scholars, Kavindra Saraswati, a major exponent of NavyaNyaya (New Logic) School of Kashi. Apart from being an eminent philosopher, his command over Sanskrit and Persian languages was exceptionally immaculate. Danishmand Khan, one of the Mughal chiefs and an admirer of Dara and Bernier, the French traveller, physician and author who enjoyed Danishmand Khan's patronage also frequented the sessions of translation of the Upanishads. The Upanishadic hymns used to be recited, explained in Sanskrit and Persian. And with the approval of Kavindra Saraswati the translation used to be finalised. Dara's insistence was that if there was similar or resembling pronouncement in Persian discourse particularly Sufi poetry that may be added to the translation. In a way it was translation with latitude. But it shows Dara's keen consciousness of the community of the target readership because similarity or resemblance will persuade the readership to own an alien text and its ideas. The positive reception of the Upanishads in Persia and the use of Dara's translation into European languages led to the circulation of the Upanishads in Europe. Without him, 'the great secret' of the Upanishads would have been limited to Sanskrit scholars in Indian shores. In fact his translations rank him as the foremost cultural and intellectual ambassadors of India to the Persian and then European worlds.

For celebrating Translation Day, we discussed various alternatives like Narada, Hermes, Kumarajiva and Dara in the preceding paragraphs. It is possible to think of other names. In fact, every Indian language would have at least a couple of names that 
with their contribution to their languages may claim to have Translation Day after them. Among the four names, stipulated earlier, the first two may be disqualified because of their divinity. In case of the third i.e., Kumarajiva despite his enormous contribution to the field of translation, it is not possible to ascertain the date of birth or death due to the absence of authentic evidence necessary for the purpose. But in case of Dara Shikoh, the problem of lack of historical evidence about the dates does not arise, as dates in his case are known to us. Why can't we then as a politically and intellectually independent nation think of 20th or 30th August as the dates for at least National Translation Day?

The question then would be: How to celebrate National Translation Day?

Translation is an act of cultural modesty, of acceptance of existence of other, and of making it one's own through the act of translation. It is not an act of dis/play of binaries between source text and target text that hierarchy-ridden minds see it but of transcending binaries through the act of reception and acceptance.

Translation Day is a metaphor for celebration of translation, its practice and critique. It should not be squandered by yet other harangues on the importance of translation. The need is to cultivate the culture of translation with full realization of the fact that translation is indispensable for our existence, for only translating societies will survive in the days to come. Apart from cultivating the culture of translation, there is need for cultivating robust culture of criticism of translation so that bad translations do not get established as good translations. 
Let us on this Day celebrate translation for its acceptance of others, and its ability to build cultures and knowledge in them for the larger good of humanity.

* Keynote Address delivered on Translation Day, September 30, 2016, organised by Sahitya Akademi, New Delhi.

\section{Notes:}

1. According to tradition, when Kumarajiva lay on his deathbed, he told his closest disciples that his cremation would reflect his success as a translator. If he had made errors, the funeral flames would consume his entire body. If, however, he had not made errors, his tongue would remain untouched by the fire. His disciples testified that his tongue survived the cremation of his body unharmed.

\section{References:}

Dara Shikuh, Majma' Ul Baharian or The Mingling Of Two Oceans, by Prince Muhammad Dara Shikuh.(1929). Edited in the Original Persian with English Translation, notes \& variants by M. Mahfuz-ul-Haq, Kolkata: The Asiatic Society Publication, Bibliotheca Indica Series, 246 (I).

Fergusson, Neil. (2011). Civilization: West and the Rest. Allen Lane: UK.

Kumarajiva, Bhikshu Wai-tao \& Dwight Goddard. (1935) The Diamond Sutra, a Buddhist Scripture. Santa Barbara, California: D. Goddard.

Kunwar Narain. (2016). Kumarajiva: A Poem, Delhi: Rajkamal. 
Li, Jung-hsi, \& Albert A. Dalia. (2002). Lives of Great Monks and Nuns. BDK English Tripițaka, 76-III-VII, Berkeley, California: Numata Center for Buddhist Translation and Research.

Mun, Chanju. (2006). The History of Doctrinal Classification in Chinese Buddhism: A Study of the Panjiao Systems. Lanham, MD: University Press of America.

Puri, B. N. (1987). Buddhism in Central Asia. Delhi: Motilal Banarsidass Publishers Private Ltd.

Purnanda, Swami.(2008). Narada. In Hindupedia. Retrived from http://www.hindupedia.com/en/Narada

Watson, Burton. (1993). The Lotus Sutra. Translations from the Asian Classics. New York: Columbia University Press. 